\title{
1 Removing ammonia from wastewater using natural 2 and synthetic zeolites: A batch experiment
}

4 J. Canellas, A. Soares and B. Jefferson

5 School of Water, Energy and Environment, Cranfield University,

6 Bedfordshire, MK43 OAL UK

8 Corresponding authors: judith.canellas@gmail.com, b.jefferson@cranfield.ac.uk

10 Abstract

11 Ion exchange based processes for the removal of ammonium from wastewater using

12 zeolites could be an attractive additional or potentially complementary treatment

13 option for conditions that pose a challenge for biological processes, such as variable

14 load or low temperatures. A range of natural and synthetic zeolites have been studied

15 for removing ammonium from wastewater. However, the relatively low capacity of

16 zeolites and challenges regarding regeneration have so far complicated efforts in this

17 research direction. Here, we compare the most commonly used natural zeolites US-

18 Clinoptilolite, UK-Clinoptilolite, Mordenite and Chabazite (using Na- and Ca- as main

19 cation exchanger) as well as a thermally modified US-Clinoptilolite and a synthetic

20 zeolite MesoLite in terms of their capacity and regeneration efficiency to determine

21 whether a synthetic zeolite like MesoLite can address the aforementioned problems

22 related to capacity and regeneration efficiency. This investigation was performed as a

23 series of batch experiments on synthetic and real wastewater solutions. When

24 zeolites were pre-saturated with sodium ions, we found the overall highest capacity of 
$254.6 \mathrm{meq} \mathrm{g}^{-1}$ for the synthetic zeolite MesoLite, relative to a range between 1.1 and 2.1

26 meq $\mathrm{g}^{-1}$ for the natural zeolites. Ammonium adsorption capacity of MesoLite with real

27 wastewater ranged between 74 and $97 \%$ of what was observed for a synthetically

28 generated mono component solution set at approximately the same ionic load. Our

29 results indicate that MesoLite could be an appropriate media for ion-exchange based

30 tertiary treatment of wastewater.

32 Keywords: Ammonium removal, ion exchange, zeolite, capacity, selectivity

\section{1. Introduction}

35 Ammonium removal is a key component of most wastewater treatment works with

36 anticipated new pollution targets requiring a large number of sites to meet discharge

37 consents between 1 and $3 \mathrm{mg} \mathrm{NH}_{4} \mathrm{~L}^{-1}$. Whilst this is commonly achieved in

38 biological systems such as the activated sludge process, it comes with a substantial

39 energy cost which can account for $50 \%$ of the total energy demand of the process

40 (Canfield et al., 2010; McAdam et al., 2011) as well as potentially emitting the

41 greenhouse gas nitrous oxide which is 310 times more potent than carbon dioxide

42 (Huijie and Chandran, 2010). On smaller sites, especially those based on low energy

43 biological processes such as trickling filters, resilient compliance to the new

44 standards is thought to be challenging due to limitations related to controlling even

45 distribution and mass transfer (Miladinovic and Weatherley, 2008). 
46 Under the normal $\mathrm{pH}$ range of wastewater, the ammonia exists predominantly in its

47 reactive ionic form (ammonium) $\mathrm{NH}_{4}{ }^{+}$. Accordingly, it can be removed by ion

48 exchange processes where the wastewater is contacted with an ion exchange

49 material that is pre-saturated with an alternative cation, typically $\mathrm{Na}^{+}$. The ion

50 exchange material has a thermodynamic preference for the ammonium ion such that

51 it exchanges with the $\mathrm{Na}^{+}$ion and is removed. Once the media becomes saturated it

52 can be regenerated and the captured ammonia recovered (Mackinnon et.al., 2010;

53 Thornton et.al., 2007). The process works for all available cations and so there is

54 competition with the other constituents within the wastewater, mainly $\mathrm{Ca}^{2+}$ and $\mathrm{Mg}^{2+}$.

55 A variety of materials can be used in such an ion exchange process, including

56 polymer ion exchange resin as well as natural and synthetic zeolites. All these

57 materials exhibit different capacities and selectivities towards the target ion and so

58 selection of the most appropriate media is important.

59 The capacity and selectivity of the different zeolites is influenced by a combination of

60 the internal pore sizes of the lattice structure, the ratio of Si:Al and the distribution of

61 Al within the lattice frame (Inglezakis, 2005; Malovanyy et al., 2013; Wang et al.,

62 2006). The properties can be modified by pre-treatment with different cations,

63 activation agents $(\mathrm{KOH}$ and $\mathrm{NaOH})$, temperature or microwave techniques (Barrer

64 and Meier, 1959; Klieve and Semmens, 1980; Lei et al., 2008; Mackinnon et al.,

65 2010; Querol et al., 2002; Shoumkova and Stoyanova, 2013). Zeolites can be natural

66 or synthetic. Natural zeolites are formed across the world by interaction of volcanic

67 rocks and ash with alkaline underground water (Shoumkova and Stoyanova, 2013). 
68 For these natural zeolites, the purity, chemical composition, crystal size, porosity, 69 pore diameters vary and this influences their efficacy for wastewater treatment in

70 terms of their capacity and selectivity towards ammonium (Table 1). Modern synthetic

71 zeolites are made by alkali treatment of raw materials rich in silica and alumina such

72 as clays like montmorillonite and kaolinite (Basaldella et al., 1998).

73 Experiments that compare different zeolite types, are typically conducted as

74 equilibrium batch trials to assess capacity and selectivity in synthetic and real

75 systems (Table 1). A wide range of materials have been previously tested for

76 ammonium removal using natural zeolites with most studies investigating

77 Clinoptilolite due to its high relative selectivity towards ammonia and wide spread

78 availability. In fact, full scale Clinoptilolite filters were used in California from 1978 to

791993 (Svetich, 1993). Comparisons with synthetic zeolites are less common and are

80 often based on synthetic zeolite not intended for ammonia removal such as zeolite A,

81 which is applied as a builder in detergent powders and tablets for water softening

82 (Aarts et al., 2004; Dyer, 1998; Milton, 1959). Consequently, such studies tend to find

83 better efficacy for natural zeolites (Fletcher and Townsend, 1982; Hankins et al.,

84 2004; Weatherley and Miladinovic, 2004). However, Mackinon (2010) has also shown

85 the benefits of MesoLite or zeolite N, a synthetic zeolite made from Kaolinite

86 (Kingwhite 65 and Kingwhite 80) dissolved with potassium or sodium reagents heated

87 to between 65 and $100^{\circ} \mathrm{C}$.

88 To the authors knowledge no study has conducted a direct comparison of MesoLite 89 with natural zeolites (both parent and modified) for the removal of ammonia. Here, we 
90 investigate, adsorption, desorption, selectivity, cation exchange capacity (CEC) and

91 performance of six natural zeolites (US-Clinoptilolite, UK-Clinoptilolite, thermally

92 modified US-Clinoptilolite, Mordenite, Ca-Chabazite and Na-Chabazite) and the

93 synthetic zeolite MesoLite in mono and multicomponent systems in order to evaluate

94 the use of zeolites for removing ammonia from wastewater.

95 Table 1: Batch equilibrium capacities for mono and multicomponent waters.

Equilibrium capacity (meq $\mathrm{g}^{-1}$ )

\begin{tabular}{lccl}
\hline Zeolite & $\begin{array}{c}\text { Initial Concentration } \\
\left(\mathbf{m g ~ N H}_{4}{ }^{+} \mathbf{~ L}^{-1}\right)\end{array}$ & $\begin{array}{c}\text { Mono-component: } \mathbf{~ H}_{4}{ }^{+} \\
\text {synthetic solution }-\end{array}$ & \multicolumn{1}{c}{ Reference } \\
Equilibrium capacity (meq $\left.\mathbf{~}^{-1}\right)$ & \\
\hline Clinoptilolilte & 200 & 0.22 & (Hankins et al., 2004) \\
Clinoptilolilte & 10 & 0.04 & (Erdoğan and Ülkü, 2011) \\
Clinoptilolilte & $25-150$ & $0.05-0.25$ & (Karadag et al., 2006) \\
Clinoptilolilte & $10-200$ & $0.07-0.66$ & (Weatherley and \\
Mordenite & 50 & $0.07-0.80$ & Miladinovic, 2004) \\
Clinoptilolite & 1000 & 0.30 & (Lei et al., 2008) \\
Clinoptilolite & 1000 & 0.95 & (Lin et al., 2012), \\
MesoLite & & 4 & (Thornton et al., 2007) \\
\hline
\end{tabular}

97 2. Materials and methods

98 Natural UK Clinoptilolite (RS Minerals, UK), Mordenite (Newstone International,

99 Japan), synthetic MesoLite (Nanochem Pty Ltd., Australia), US Clinoptilolite,

100 Chabazite (in sodium and calcium forms), and thermally modified US Clinoptilolite

101 (St. Cloud, NM, USA) were sieved to achieve uniform media size (1 to $1.7 \mathrm{~mm}$ ) and 
102 washed in distilled water to remove particulate impurities. The zeolites were

103 preconditioned prior to testing using $1 \mathrm{M} \mathrm{NaCl}$ and $1 \mathrm{M} \mathrm{CaCl}_{2}$ (stated purity >99\%;

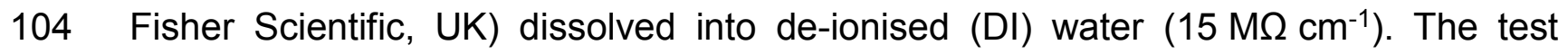
105 solution was prepared using ammonium chloride $\left(\mathrm{NH}_{4} \mathrm{Cl}\right)$ (stated purity $>99 \%$; 106 Fisher Scientific, UK) dissolved into DI water.

\section{2.1. Batch equilibrium experiment}

108 Experiments were conducted in batch using $250 \mathrm{~mL}$ Erlenmeyer flasks for each of the 109 zeolites. Different amounts of the zeolites (from 0.1 to $0.5 \mathrm{~g}$ ) were contacted with $110100 \mathrm{~mL}$ of the test solution. The synthetic ammonium solution was set at a

111 concentration of $16 \mathrm{mg} \mathrm{NH}_{4}{ }^{+} \mathrm{L}^{-1}$ (0.89 meq $\mathrm{NH}_{4}{ }^{+} \mathrm{L}^{-1}, \mathrm{pH}$ between 7 and 8$)$ for the

112 mono component experiments and compared to real wastewater from Cranfield

113 University's sewage work with an average ammonium concentration of $16 \mathrm{mg} \mathrm{NH}_{4}^{+} \mathrm{L}^{-}$

1141 . The sample of real wastewater was taken post biological treatment (trickling filter)

115 and then filtered through a $0.2 \mu \mathrm{m}$ filter to remove solids. The tested concentration in

116 the real wastewater varied between 11.9 and $16.2 \mathrm{mg} \mathrm{NH}_{4}{ }^{+} \mathrm{L}^{-1}$ at a $\mathrm{pH}$ of 7

117 corresponding to 0.9 and $0.66 \mathrm{meq} \mathrm{NH}_{4}{ }^{+} \mathrm{L}^{-1}$. The flasks were then agitated at

$118125 \mathrm{rpm}$ for up to 48 hours with samples taken at 0,20 and 40 minutes as well as 1 ,

$1192,4,6,8,12,24$ and 48 hours. Equilibrium was reached for all zeolite types within 12024 hours.

121 Equilibrium data for each of the zeolites was then compared to both Freundlich and

122 Langmuir isotherm models (Almutairi et al., 2015; Karadag et al., 2006; McAdam et 
123 al., 2011). The ammonium concentration was determined spectrometrically by cell

124 test (Merck, Germany) using a spectrophotometer (Merck, Spectroquant Nova 60,

125 Germany). With this method there is no interference by other dissolved species (e.g.

126 cations, anions) in the liquid phase. The concentration of $\mathrm{Na}^{+}, \mathrm{Ca}^{2+}, \mathrm{K}^{+}$and $\mathrm{Mg}^{2+}$

127 were analysed by atomic absorption spectroscopy (AAS) (Aanalyst 800, PerkinElmer,

128 UK). The concentration of ions in the solid phase was calculated using the following

129 mass balance equation (Jorgensen et al., 1976). The experiments were conducted in

130 duplicate.

$$
Q_{e}=\frac{\left(C_{o}-C_{e}\right) V}{M}
$$

Equation 1

131 where $Q_{e}$ is the amount of ions in the solid phase $\left(\mathrm{mg} \mathrm{g}^{-1}\right)$ or [meq g${ }^{-1}$, $C_{o}$ is the initial

132 ion concentration in solution $\left(\mathrm{mg} \mathrm{L}^{-1}\right)\left[\mathrm{meq} \mathrm{L}^{-1}\right], \mathrm{C}_{\mathrm{e}}$ is the ion concentration remaining

133 in solution at equilibrium ( $\left.\mathrm{mg} \mathrm{L}^{-1}\right)\left[\mathrm{meq} \mathrm{L}^{-1}\right], \mathrm{V}$ is the solution volume $(\mathrm{L})$ and $\mathrm{M}$ is the

134 mass of zeolite media introduced $(\mathrm{g})$.

\section{2.2. Regeneration}

136 Following the adsorption process, the zeolites were contacted with $1 \mathrm{M} \mathrm{NaCl}$ for $24 \mathrm{~h}$

137 and the amount of ammonium released into solution was measured. The recovered

138 capacity was then determined for both synthetic and real wastewater solution

139 throughout an adsorption phase of $24 \mathrm{~h}$ to assess the new capacity. That value was

140 then compared to the capacity obtained on the previous adsorption experiment when

141 non-pretreated zeolite was used. 


\section{2.3. Saturation capacity}

143 The saturation capacity of the test zeolite was established through a fed-batch

144 experiment using $0.3 \mathrm{~g}$ of zeolite (Cooney, 1999). The zeolites were prepared in

$145100 \mathrm{~mL}$ test solution that contained $\mathrm{NH}_{4} \mathrm{Cl}$ at a concentration of $600 \mathrm{mg} \mathrm{L}^{-1}$ and were

146 then agitated for $24 \mathrm{~h}$. After this time, $50 \mathrm{~mL}$ of the solution was withdrawn and

147 replaced with a fresh $50 \mathrm{~mL}$ of test solution. These steps were repeated until no more

148 exchange of $\mathrm{NH}_{4}{ }^{+}$was measured.

\section{2.4. Cation exchange capacity (CEC)}

150 The CEC was evaluated for the following ions: $\mathrm{Ca}^{2+}, \mathrm{Na}^{+}, \mathrm{K}^{+}$and $\mathrm{Mg}^{2+}$ following the

151 ammonium acetate method number 16 of the MAFF Reference Book RB427. For that

152 method, $20 \mathrm{ml}$ of $1 \mathrm{M}$ ammonium acetate solution (stated purity $>99 \%$, Fisher

153 Scientific, UK) was contacted with $5 \mathrm{~g}$ of zeolites sieved to a size between 1 and

$1541.7 \mathrm{~mm}$ after being pre-conditioned with $\mathrm{NaCl}$. After $24 \mathrm{~h}$ of contact, the solution was

155 filtered and the zeolite was leached with $1 \mathrm{M}$ ammonium acetate until $250 \mathrm{ml}$ were

156 collected (Faithful ,1986).

157 To determine the CEC of $\mathrm{Ca}^{2+}$ and $\mathrm{Mg}^{2+}, 2.5 \mathrm{~mL}$ of strontium chloride (stated purity $158>99 \%$; Fisher Scientific, UK) were added to a volumetric flask of $100 \mathrm{~mL}$. The 159 volume was increased up to $25 \mathrm{~mL}$ using $1 \mathrm{M}$ of ammonium acetate. The capacity for $160 \mathrm{Ca}^{2+}$ and $\mathrm{Mg}^{2+}$ of each zeolite was calculated through the equations below:

meq $C a / 100 g=\frac{\left(C a_{s}-C a_{b}\right) \times 6.25}{v}$ 
meq $M g / 100 g=\frac{\left(M g_{s}-M g_{b}\right) \times 10.3}{v}$

Equation 3

161 where $\mathrm{Ca}_{\mathrm{s}}$ is the concentration of calcium in the sample extract $\left(\mu \mathrm{g} \mathrm{mL}^{-1}\right), \mathrm{Cab}_{\mathrm{b}}$ is the

162 concentration of calcium in the blank extract $\left(\mu \mathrm{g} \mathrm{mL}^{-1}\right), \mathrm{Mgs}_{\mathrm{s}}$ is the concentration of

163 magnesium in the sample extract $\left(\mu \mathrm{g} \mathrm{mL}^{-1}\right), \mathrm{Mg}_{\mathrm{b}}$ is the concentration of magnesium in

164 the blank extract $\left(\mu \mathrm{g} \mathrm{mL}^{-1}\right)$ and $\mathrm{v}$ is the aliquot volume $(\mathrm{mL})$.

165 To determine the CEC of $\mathrm{Na}^{+}$and $\mathrm{K}^{+} 10 \mathrm{ml}$ of the extract were diluted to $25 \mathrm{ml}$ using

$1661 \mathrm{M}$ ammonium acetate. Equation 5 and 6 were used to calculate the capacity for $\mathrm{Na}^{+}$

167 and $\mathrm{K}^{+}$for each zeolite respectively

meq $N a / 100 g=\frac{\left(N a_{s}-N a_{b}\right) \times 5.4375}{v}$

Equation 4

meq $K / 100 g=\frac{\left(K_{s}-K_{b}\right) \times 3.2}{v}$

Equation 5

168 where $\mathrm{Na}_{s}$ is the concentration of sodium in the sample extract $\left(\mu \mathrm{g} \mathrm{mL}^{-1}\right), \mathrm{Na}_{b}$ is the 169 concentration of sodium in the blank extract $\left(\mu \mathrm{g} \mathrm{mL}^{-1}\right), \mathrm{K}_{\mathrm{s}}$ is the concentration of

170 potassium in the sample extract $\left(\mu \mathrm{g} \mathrm{mL}^{-1}\right), \mathrm{Kb}$ is the concentration of potassium in the

171 blank extract $\left(\mu \mathrm{g} \mathrm{mL}^{-1}\right)$ and $\mathrm{v}$ is the aliquot volume in $\mathrm{mL}$, of the sample used.

\section{2.5. Isotherm modelling}

173 Batch equilibrium data is commonly analysed with respect to empirical isotherm

174 models such as the Langmuir or Freundlich models. Both were originally developed

175 for gas adsorption in mono component systems but are now widely applied to liquid 
176 adsorption, and particularly also ion exchange in mono-, binary- and multicomponent

177 systems (Karadag et al., 2006; Mohan and Singh 2002; Thornton et al., 2007).

178 The Langmuir model is based on the concept of constant site energy that assumes

179 one solute molecule per site and constant cation capacity for each exchangeable site

180 (monolayer adsorption), (Wang et al., 2007; Mohan and Singh, 2002) and is

181 expressed as

$q_{e}=\frac{q_{\max } b C_{e}}{1+b C_{e}} \quad$ Non-linear form

Equation 6

$\frac{C_{e}}{q_{e}}=\left(\frac{1}{q_{\max b}}\right)+\left(\frac{1}{q_{\max }}\right) C_{e} \quad$ Linear form

Equation 7

182 where $\mathrm{q}_{\mathrm{e}}$ is the amount of solute adsorbed per unit of weight of adsorbent $\left(\mathrm{mg} \mathrm{g}^{-1}\right)$,

$183 \mathrm{C}_{\mathrm{e}}$ is the equilibrium concentration of solute in the bulk solution $\left(\mathrm{mg} \mathrm{L}^{-1}\right), \mathrm{q}_{\max }$ is the

184 monolayer adsorption capacity $\left(\mathrm{mg} \mathrm{g}^{-1}\right)$ and $\mathrm{b}$ is the constant related to the free

185 energy of adsorption $\left(b \sim e^{-\Delta G / R T}\right)$. It is reciprocal to the concentration at which half the

186 saturation of the adsorbent is attained.

187 The Freundlich model describes a logarithmic relationship between solid and solution

188 concentration assuming that the adsorbent has a heterogeneous surface with non-

189 uniform distribution of adsorption sites (Mohan and Singh, 2002; Lin et al., 2012). The

190 Freundlich equation can be written as

$q_{e}=K_{F} C_{e}^{1 / n} \quad$ Non-linear form,

Equation 8 
$\log q_{e}=\log K_{F}+\frac{1}{n} \log C_{e} \quad$ Linear form,

Equation 9

191 where $\mathrm{q}_{\mathrm{e}}$ is the amount of solute adsorbed per unit of weight of adsorbent $\left(\mathrm{mg} \mathrm{g}^{-1}\right)$,

$192 \mathrm{C}_{e}$ is the equilibrium concentration of solute in the bulk solution ( $\left.m g \mathrm{~L}^{-1}\right), \mathrm{K}_{F}$ is the 193 constant indicative of the relative adsorption capacity of the adsorbent $\left(\mathrm{mg} \mathrm{g}^{-1}\right)$ and $1941 / n$ is the constant indicative of the intensity of the adsorption (Mohan and Singh, 195 2002). Strictly speaking, the models should only be applied to mono component 196 systems and when used beyond that, it is customary to compare the model constant 197 as an indication of the impact of competing species rather than for prediction.

\section{3. Results and discussion}

\subsection{Comparison of capacity in mono component solution}

201 The equilibrium capacity of the different zeolites ranged from 1.15 to 4.6 meq $202 \mathrm{NH}_{4}^{+} \mathrm{g}^{-1}$ when in the sodium $\left(\mathrm{Na}^{+}\right)$form and 0.15 to $1.45 \mathrm{meq} \mathrm{NH}_{4}{ }^{+} \mathrm{g}^{-1}$ when in the 203 calcium $\left(\mathrm{Ca}^{2+}\right)$ form with an initial $\mathrm{NH}_{4} \mathrm{Cl}$ of $600 \mathrm{mg} \mathrm{NH}_{4}{ }^{+} \mathrm{L}^{-1}$ (33.3 meq $\mathrm{NH}_{4}{ }^{+} \mathrm{L}^{-1}$ ) 204 (Fig.1). Importantly, the synthetic zeolite, MesoLite, showed a higher equilibrium 205 capacity and selectivity than all the natural zeolites regardless of which pre-treatment 206 was used. This difference due to pre-treatment $\left(\mathrm{Na}^{+}\right.$or $\left.\mathrm{Ca}^{2+}\right)$ in all zeolites is in 207 accordance with previous studies of both natural and synthetic zeolites (Metropoulos 208 et al., 1993; Lei et al., 2008). The capacity reduction associated with calcium pre- 
209 treatment is sensible given the known selectivity coefficient for the zeolites of 5.37 for

$210 \alpha \mathrm{NH}_{4}+\mathrm{Na}+, 2.2$ for $\alpha \mathrm{NH}_{4}+, \mathrm{Ca} 2+$ and 1.97 for $\alpha \mathrm{Na}^{+}, \mathrm{Ca} 2+$ (Hankins et al., 2004; Jama and

211 Yocel, 1989; Watanabe et al., 2004). The results highlight the significance of the

212 presaturant ion initially associated with the zeolite and aligns with simulations that

213 have shown that $\mathrm{Na}^{+}$yields a lower energy state within the lattice than $\mathrm{Ca}^{2+}$

214 (Channon et al., 1998).

215 The thermally modified US-Clinoptilolite and Mordenite were affected most negatively

216 by pre-treatment with $\mathrm{Ca}^{2+}$, with a reduction in capacity of 91 and $88 \%$ respectively,

217 compared to pre-treatment with $\mathrm{Na}^{+}$. In comparison, the capacity of MesoLite 218 reduced by $68 \%$ indicating a slightly higher resilience in terms of selectivity towards 219 ammonium ions. Interestingly, the three Clinoptilolite materials in the sodium form, 220 showed a variation of $35 \%$ with regard to capacity; $1.72,1.19$ and $1.15 \mathrm{meq} \mathrm{NH}_{4}^{+} \mathrm{g}^{-1}$ 221 for the US, thermally modified US and the UK samples respectively. This confirms 222 previous reports about the potential variability in the properties of natural zeolites 223 such that capacities need to be confirmed when switching the origin of the material 224 (Almutairi et al., 2015; Erdoğan and Ülkü, 2011). 


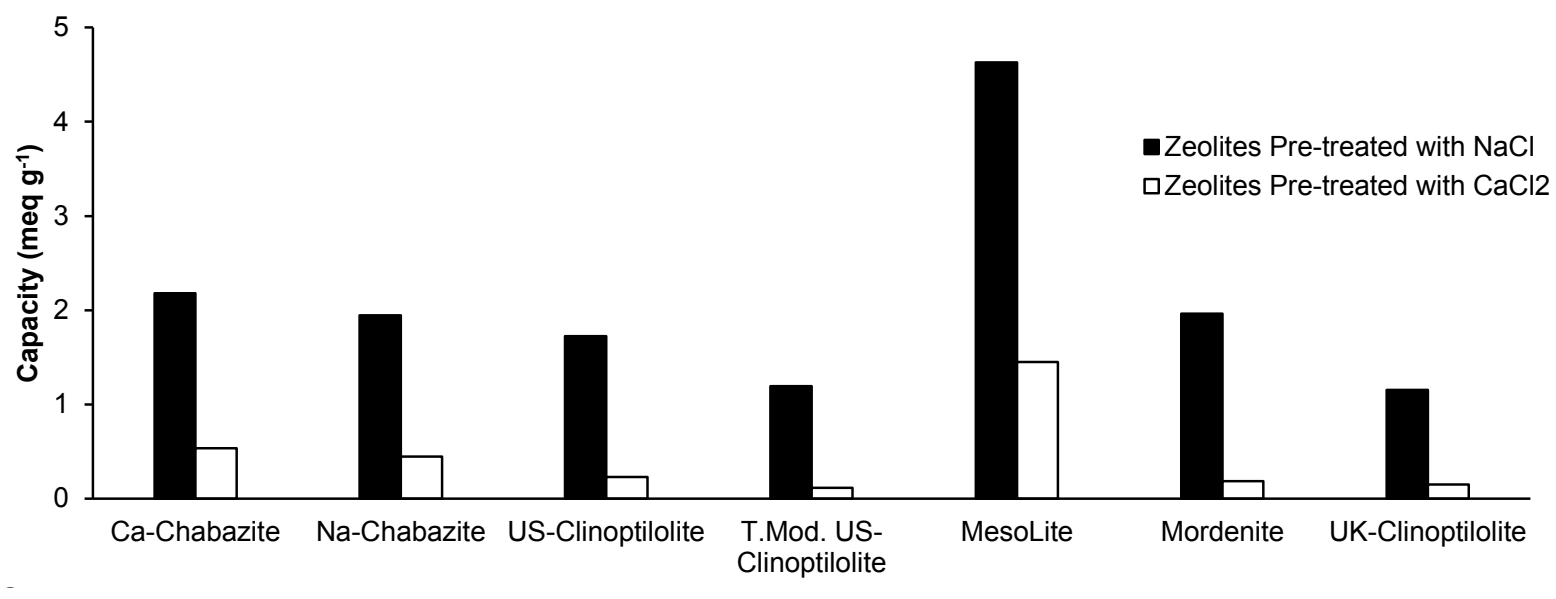

226 Fig. 1: Equilibrium batch saturation capacity against a synthetic mono component 227 solution (125 rpm; $\mathrm{C}_{0}=600 \mathrm{mg} \mathrm{L}^{-1}\left(33.3 \mathrm{meq} \mathrm{L}^{-1}\right)$ during 5 cycles to ensure complete 228 saturation; $\mathrm{pH}=7$ ) using $1 \mathrm{M}$ of $\mathrm{NaCl}$ and $\mathrm{CaCl}_{2}$ as a pre-treatment for seven different 229 zeolites (1 $\mathrm{g}$ of zeolite).

230 Comparison to the base properties of the different zeolites indicates that the Si:Al 231 ratio may account for the difference between the observed capacity of MesoLite and 232 the natural zeolites. To illustrate, the Si:Al ratio is $>4: 1,4: 1,4: 1,5: 1$ and $1: 1$ for 233 Clinoptilolite, Na-Chabazite, Ca-Chabazite, Mordenite and MesoLite respectively. 234 Whereas the effective window size was $4.6,7.4,7.4,6.7$ and $5.7 \AA$ respectively for

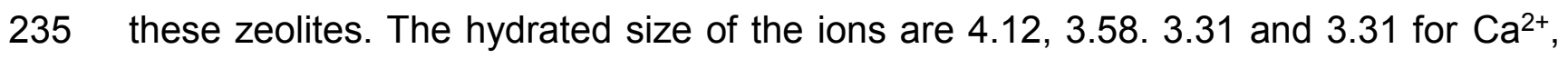
$236 \mathrm{Na}^{+}, \mathrm{K}+$ and $\mathrm{NH}_{4}^{+}$respectively such that size exclusion is unlikely to be significantly 237 different between the zeolites (Hankins et al., 2004). Instead the much lower Si:Al 238 ratio leads to a lattice structure with more exchange sites and hence an increased 239 overall capacity (Armbruster and Gunter, 2001; Channon et al., 1998; Ruiz-Salvador 240 et al.,1998). 


\section{3.2. Capacity with real wastewater}

242 The seven zeolites were compared in terms of their equilibrium capacity when

243 treating real wastewater effluent. Two different samples were required to test the full

244 range of zeolites and the properties of the wastewater changed between the two

245 samples (Table 2). The effluent was sourced post a trickling filter with a pH of 7.2 for

246 the first sample and 7.3 for the second sample indicating that ammonium ions are

247 likely to predominate. The actual concentration of ammonium ions within the sample

248 was 16.2 and $11.7 \mathrm{mg} \mathrm{NH}_{4}{ }^{+} \mathrm{L}^{-1}$ (0.9 and $\left.0.65 \mathrm{meq} \mathrm{NH}_{4}{ }^{+} \mathrm{L}^{-1}\right)$ compared to calcium

249 concentrations of 62.8 and $51.4 \mathrm{mg} \mathrm{NH}_{4}{ }^{+} \mathrm{L}^{-1}$ (3.14 and $\left.2.57 \mathrm{meq} \mathrm{NH}_{4}{ }^{+} \mathrm{L}^{-1}\right)$ and

250 sodium of 100 and $67.16 \mathrm{mg} \mathrm{NH}_{4}+\mathrm{L}^{-1}$ (4.37 and $\left.2.92 \mathrm{meq} \mathrm{NH}_{4}^{+} \mathrm{L}^{-1}\right)$. To adequately

251 compare capacity for the real wastewater, a synthetic solution was created using the

252 average $\mathrm{NH}_{4}-\mathrm{N}$ concentration of the secondary effluent of $16 \mathrm{mg} \mathrm{NH}_{4}{ }^{+} \mathrm{L}^{-1}$ (0.8 meq

$\left.253 \mathrm{NH}_{4}{ }^{+} \mathrm{L}^{-1}\right)$.

254 Table 2: Characterization of the real effluent.

\begin{tabular}{|c|c|c|c|c|c|c|c|}
\hline $\begin{array}{l}\text { Aerobic } \\
\text { effluent }\end{array}$ & Zeolites & $\begin{array}{l}\text { Total } \\
\left(\text { meq } L^{-1}\right)\end{array}$ & $\begin{array}{c}\mathrm{NH}_{4}^{+} \\
\left(\mathrm{meq} \mathrm{L}^{-1}\right)\end{array}$ & $\begin{array}{c}\mathrm{Ca}^{2+} \\
\left(\mathrm{meq} \mathrm{L} \mathrm{L}^{-1}\right)\end{array}$ & $\begin{array}{c}\mathrm{Na}^{+} \\
\left(\mathrm{meq} \mathrm{L}^{-1}\right)\end{array}$ & $\begin{array}{l}\mathrm{K}^{+} \\
\left(\mathrm{meq} \mathrm{L}^{-1}\right)\end{array}$ & $\begin{array}{l}\mathrm{Mg}^{2+} \\
\left(\mathrm{meq} \mathrm{L}^{-1}\right)\end{array}$ \\
\hline Day 1 & $\begin{array}{l}\text { MesoLite, US- } \\
\text { Clinoptilolite, } \mathrm{Na} \text { and Ca- } \\
\text { Chabazite }\end{array}$ & 9.96 & 0.90 & 3.1 & 4.4 & 0.47 & 0.74 \\
\hline Day 3 & $\begin{array}{l}\text { T. Mod. US-Clinoptilolite, } \\
\text { Mordenite and UK- } \\
\text { Clinoptilolite }\end{array}$ & 7.44 & 0.66 & 2.6 & 3 & 0.46 & 0.71 \\
\hline
\end{tabular}


256 A comparison of the zeolites revealed that for all zeolite masses tested, MesoLite 257 was able to remove more ammonium than the other zeolites. To illustrate, the 258 removal efficiency of ammonium with MesoLite increased by 67 to $93 \%$ when the 259 mass of zeolite added increased from 0.1 to $0.5 \mathrm{~g}$ (Fig. 2). In comparison, the worst 260 performing zeolite was UK Clinoptilolite where the removal efficiency increased by 10 261 to $73 \%$ for the same increase in zeolite mass. The best performing zeolite in this 262 aspect was the thermally modified Clinoptilolite where removal efficiency increased 263 by 36 to $84 \%$ over the range of added masses that were tested. Whilst removal 264 increased with the added mass, the capacity decreased with MesoLite, which was the 265 most affected in terms of absolute capacity. In fact, the capacity of UK Clinoptilolite 266 did not vary much with added mass with capacities between 0.115 and $2670.166 \mathrm{meq} \mathrm{NH}_{4}{ }^{+} \mathrm{g}^{-1}$ compared to MesoLite where the capacity varied between 0.16

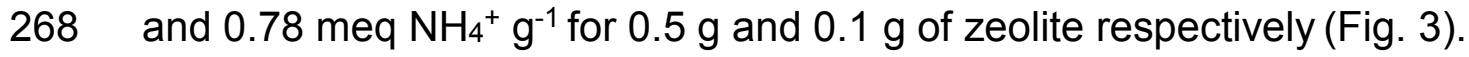

269 Overall, MesoLite demonstrated the highest capacity for ammonium and the least 270 relative reduction in ammonium capacity in presence of competing species. For 271 instance, the reduction in capacity from switching from the mono component system

272 to the real wastewater ranged from 3 to $26 \%$ for $0.5 \mathrm{~g}$ to $0.1 \mathrm{~g}$ of zeolite. In 273 comparison, a greater impact as a result of competition was observed for the natural 274 zeolites ranging between 40 and $80 \%$ for $0.1 \mathrm{~g}$ of zeolite and between 16 and $50 \%$ 275 for $0.5 \mathrm{~g}$ of zeolite (Fig. 3). Therefore, the higher capacity numbers are associated 276 with the smaller masses of added zeolite where there are less total available 277 exchange sites. This occurs when the actual levels of ammonium removal are low 
278 with values ranging between 10 and $40 \%$ (Fig. 2). Increasing the removal efficiency

279 by adding more zeolite then reduces the percentage of the capacity associated with

280 ammonium reflecting an inefficiency which is much less pronounced in the case of

281 MesoLite.

282

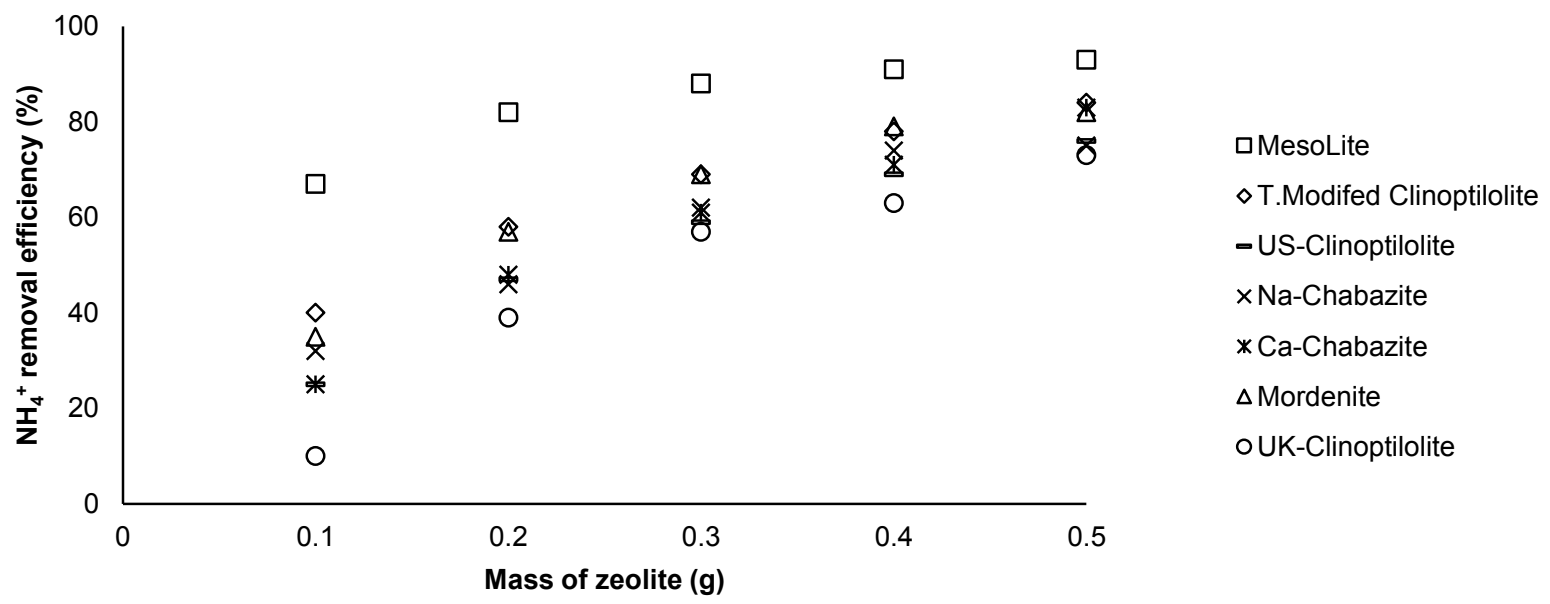

284 Fig. 2: Removal efficiency of ammonium for different masses of adsorbent in real 285 wastewater effluent. 


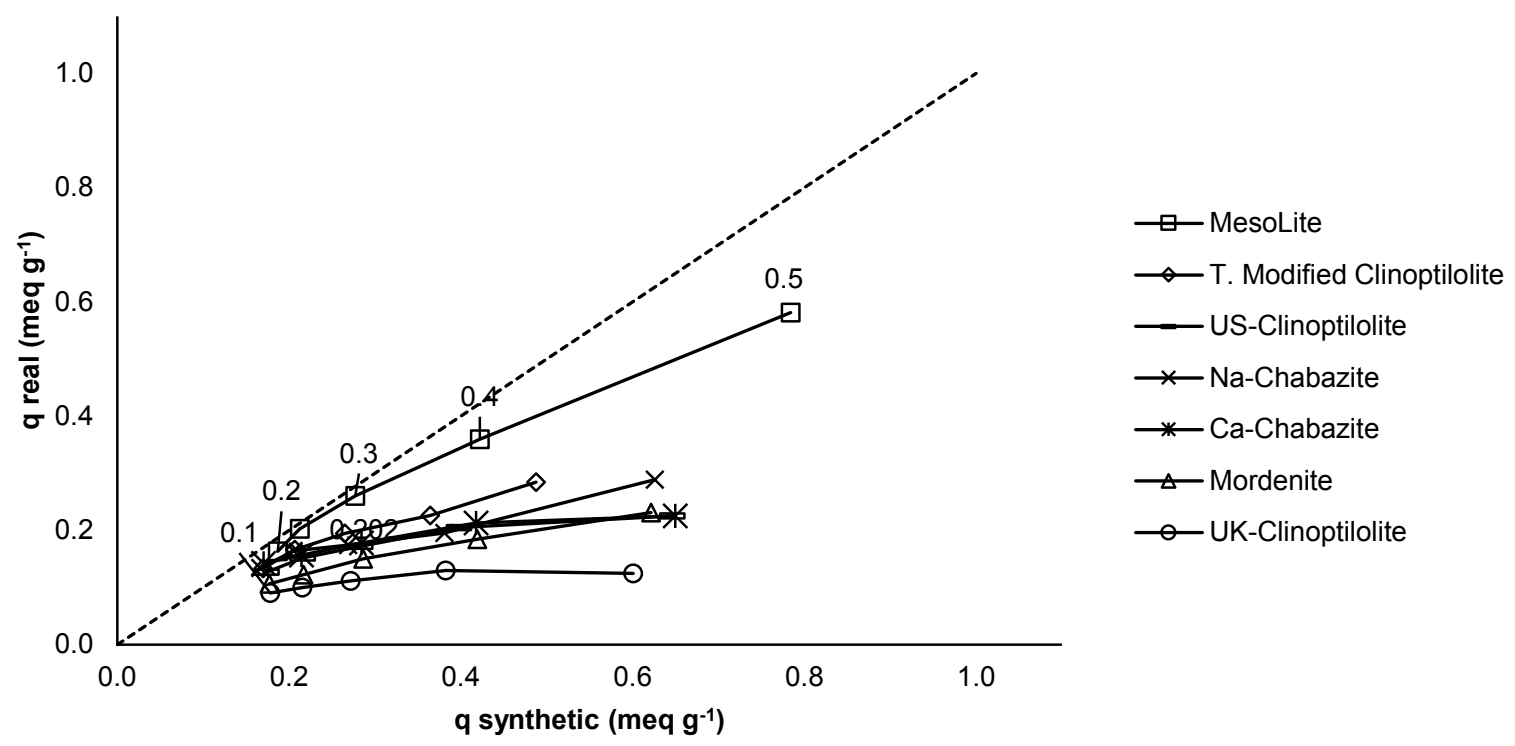

288 Fig. 3: Comparison of batch capacity in real and synthetic effluents at five different 289 zeolite masses (0.1 to $0.5 \mathrm{~g})$. [125 rpm; $\mathrm{C}_{\mathrm{o}}=16 \mathrm{mg} \mathrm{L}^{-1}\left(0.8 \mathrm{meq} \mathrm{NH}_{4}^{+} \mathrm{L}^{-1}\right)$; $\left.\mathrm{pH}=7\right]$.

291 Further analysis of the removal of the different ions from the real wastewater revealed 292 substantial uptake of $\mathrm{Ca}^{2+}$ with additional removal of $\mathrm{K}^{+}$and $\mathrm{Mg}^{2+}$ for some of the 293 natural zeolites (Fig. 4). To illustrate: When adding $0.1 \mathrm{~g}$ of zeolite the capacity with 294 respect to $\mathrm{Ca}^{2+}$ was $0.25,0,0.35,0.97,1.01,0.25$ and 0.24 meq g$^{-1}$ for MesoLite, 295 thermally modified US Clinoptilolite, US Clinoptilolite, Na-Chabazite, Ca-Chabazite, 296 Mordenite and UK Clinoptilolite respectively. This represented $30 \%, 0 \%, 55 \%$, $29772 \%, 78 \%, 46 \%$ and $60 \%$ of the total uptake. Even though the thermally modified 298 Clinoptilolite does not adsorb any $\mathrm{Ca}^{2+}$, MesoLite has better capacity and selectivity 299 towards ammonium (Fig.4 (A)). When increasing the mass of zeolite to $0.5 \mathrm{~g}$, five 300 times as many exchange sites were available. This decreased overall capacity, 
301 indicating that a significant number of sites were still available, which made it possible 302 for other ions to be captured. For instance, it was observed that there was an

303 additional capacity for $\mathrm{K}^{+}$for all natural zeolites, in comparison to just for thermally 304 modified US Clinoptilolite, Na-Chabazite and Ca-Chabazite when only $0.1 \mathrm{~g}$ of zeolite 305 was added. Further, when the higher mass of $0.5 \mathrm{~g}$ of zeolite was added, $\mathrm{Mg}^{2+}$ was 306 also taken up by all the zeolites with the exception of thermally modified US 307 Clinoptilolite (Fig. 4 (B)). The corresponding percentage of the capacity associated 308 with ammonium was $38 \%$ for MesoLite which removed $93 \%$ of the available 309 ammonium from the water. The equivalent percentage of the uptake associated with 310 ammonium was lower for all the natural zeolites and ranged between 24 and $40 \%$.

311 The fact that when using $0.5 \mathrm{~g}$ of zeolite, the reduction in ammonium capacity (14 to $31239 \%$ ) and the percentage of the total capacity associated with ammonium (41 to $31325 \%$ ) were different, indicates, that the systems are not utilising all the available 314 sites. For instance, the overall saturation CEC of MesoLite for $\mathrm{NH}_{4}^{+}$is $4.6 \mathrm{meq} \mathrm{NH}_{4}^{+} \mathrm{g}^{-}$ 3151 , thus indicating that the experiments conducted here were utilising around 13 and $3163.5 \%$ of the totally available active sites for 0.1 and $0.5 \mathrm{~g}$ respectively. 


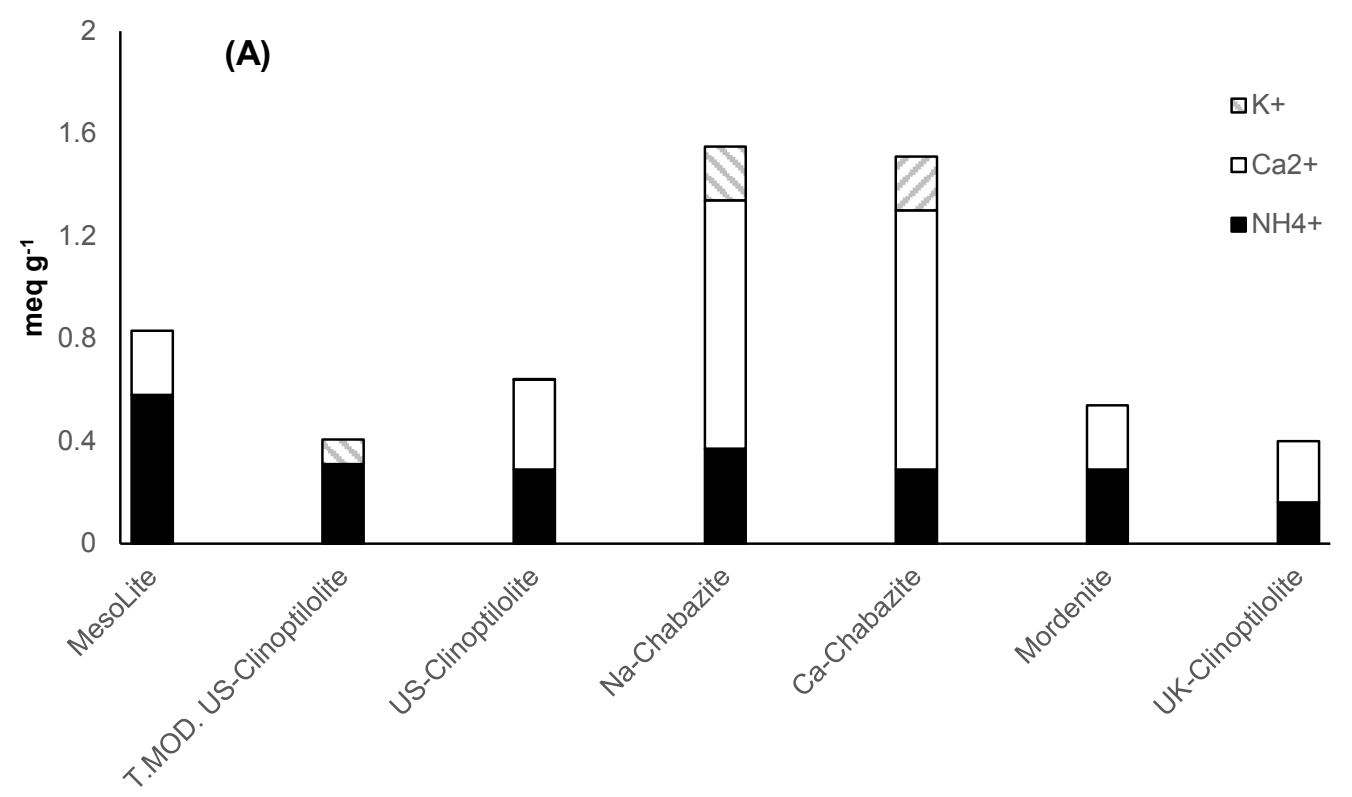

318

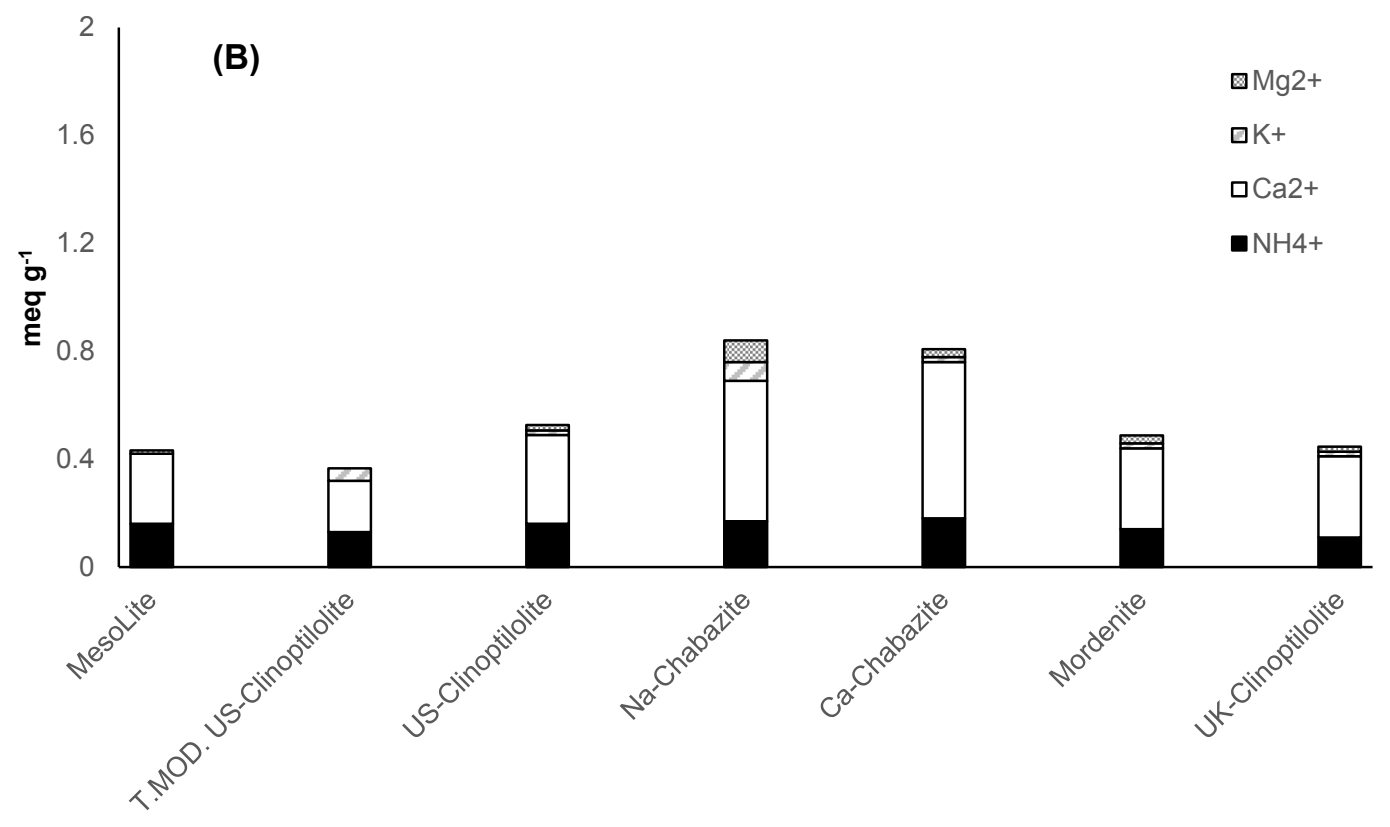

320 Fig. 4: Comparison of adsorbance of competing cations $\left(\mathrm{Ca}^{2+}, \mathrm{Mg}^{2+}\right.$ and $\left.\mathrm{K}^{+}\right)$with the 321 adsorbance of $\mathrm{NH}_{4}{ }^{+}$for (A) $0.1 \mathrm{~g}$ of zeolite and (B) $0.5 \mathrm{~g}$ of zeolite. 
322 This outcome supports previous results with Clinoptilolite, where a selectivity

323 sequence of $\mathrm{Ca}^{2+}>\mathrm{K}^{+}>\mathrm{Mg}^{2+}$ was reported during synthetic trials (Metropoulos et al.,

324 1993; Weatherley and Miladinovic, 2004). This was extended to include ammonium

325 with a sequence of $\mathrm{NH}_{4}{ }^{+}>\mathrm{Na}^{+}>\mathrm{Ca}^{2+}$ during investigation into the use of Clinoptilolite

326 for the treatment of landfill leachate (Hankins et al., 2004). However, it has been

327 previously suggested that calcium would not adversely affect uptake of most metallic

328 ions onto Clinoptilolite and Chabazite when the concentration is below 10 meq L$^{-1}$

329 with a dramatic reduction in ammonium removal expected once the $\mathrm{Ca}^{2+}$

330 concentration exceeds 25 meq L-1 (Ouki and Kavannagh, 1997). In the present study

$331 \mathrm{Ca}^{2+}$ concentrations were lower than 25 meq L-1 and showed a substantial impact.

332 This is similar to previous work on landfill leachate where an addition of calcium

333 reduced ammonium capacity by $21 \%$ in a $0.16 \mathrm{~N}$ ionic solution (Hankins et al., 334 2004).

335 The relative impact of competing ions on the uptake of ammonium for the different

336 zeolites reflects a combination of the different concentrations of each component and

337 the differences in the ion (size and energy of hydration) and zeolite (aluminium

338 distribution and Si:Al ratio) properties (Channon et al., 1998). The fact that uptake of

339 calcium was maximised for the zeolite Chabazite is in line with this idea, as the

340 zeolite has a relatively low charge in the framework (Si:Al $=4)$ and the largest

341 effective window size of the tested zeolites at $7.37 \AA$ compared to $5.97 \AA, 6.7 \AA$ and

$3425.7 \AA$ for Clinoptilolite, Mordenite and MesoLite respectively. The other feature is the

343 properties of the ions themselves in relation to the free energy of hydration. If all other 
344 features are fixed, the selectivity sequence in low concentration systems is reported

345 to mirror the free energy of hydration with lower free energies reducing preference

346 (Kantiranis et al., 2011a). This is because ions with higher free energy of hydration

347 are more likely to shed water molecules and form inner sphere complexes with the

348 zeolite structure (Kantiranis et al., 2011b). Further, uptake of $\mathrm{Mg}^{2+}$ and $\mathrm{K}^{+}$became

349 significant only when the total number of sites was increased, reflecting their position

350 further down the selectivity sequence which is consistent with their lower free energy

351 of hydration and their larger effective ionic size (Eisenman, 1962; Sherry, 1966).

\section{3.3. Isotherm models}

353 Both isotherm models appropriately represented the equilibrium data although in the

354 cases of UK Clinoptilolite and Na-Chabazite, the Freundlich model was found to be a

355 more representative fit to the data since this model assumes non-distribution of

356 adsorption and it assumes a heterogeneous surface. The Freundlich constant $\left(\mathrm{K}_{\mathrm{f}}\right)$ for

357 MesoLite decreased from $7.2 \mathrm{mg} \mathrm{NH}_{4}{ }^{+} \mathrm{g}^{-1}$ in the mono component system to $2.7 \mathrm{mg}$

$358 \mathrm{NH}_{4}{ }^{+} \mathrm{g}^{-1}$ in the multicomponent batch test (Fig. 5 and Fig. 6). The equivalent

359 decrease in $K_{f}$ for the natural zeolites were $70,69,61,64,40$, and $50 \%$ for US-

360 Clinoptilolite, Mordenite, UK-Clinoptilolite, Ca-Chabazite, Na-Chabazite and thermally

361 modified US-Clinoptilolite respectively. Comparison to previously reported values for

362 Clinoptilolite show a large range of values (Table 3 ) reflecting the limitation of the

363 models for comparison between studies. Accordingly, Inglezakis (2005) suggests that

364 the isotherm coefficients are only true for the specific experimental conditions used,

365 such that comparison across different studies should be done very carefully. 

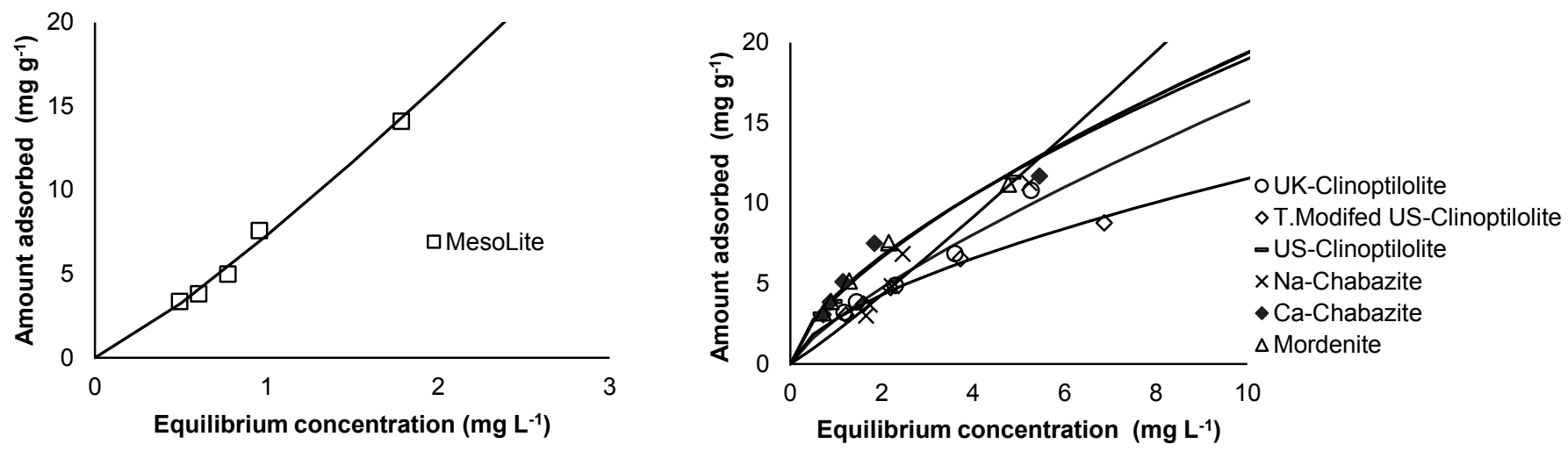

366 Fig. 5: Comparison of the isotherm curves for the different zeolites fitted with a 367 Freundlich model when treating a mono-component synthetic solution at an initial 368 concentration of $16 \mathrm{mg} \mathrm{NH}_{4}{ }^{+} \mathrm{L}^{-1}$ and a pH of 7.5. (A) For MesoLite and (B) for the 369 natural zeolites.
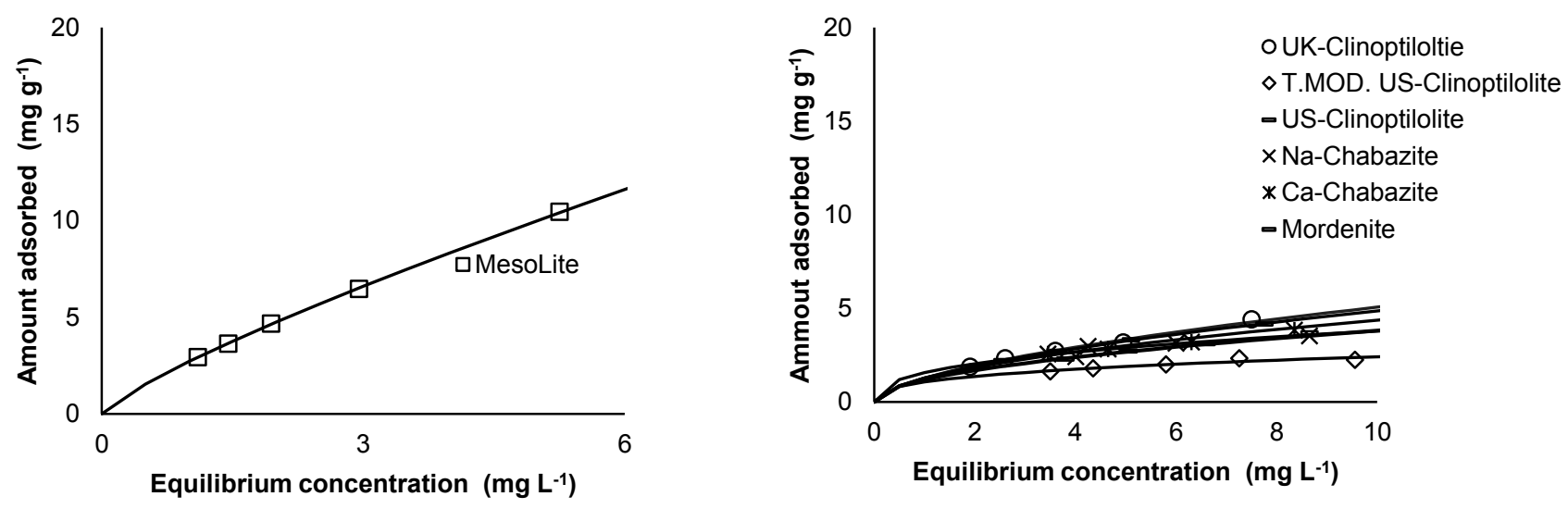

370 Fig. 6: Comparison of the isotherm curves for the different zeolites fitted with a 371 Freundlich model when treating a multi-component real wastewater at an initial 372 concentration of 11.7 to $11.2 \mathrm{mg} \mathrm{NH}_{4}{ }^{+} \mathrm{L}^{-1}$ and a pH of 7. (A) For MesoLite and (B) for the 373 natural zeolites. 
375 Table 3: Langmuir $\left(q_{m}\right)$ and Freundlich $\left(K_{F}\right)$ constants for different experimental 376 setups.

\begin{tabular}{|c|c|c|c|c|}
\hline Material & Experimental conditions & $\mathbf{q}_{\mathrm{m}}$ & $\mathbf{K}_{\mathbf{F}}$ & Reference \\
\hline \multirow[t]{3}{*}{ Clinoptilolite } & \multirow{3}{*}{$\begin{array}{l}\text { Concentration range of } \mathrm{NH}_{4}^{+}(23 \text { to } \\
\left.113 \mathrm{mg} \mathrm{L}^{-1}\right) \text { in three different particle } \\
\text { sizes }\end{array}$} & 2.128 & 0.428 & \multirow{3}{*}{ (Wang et al., 2006) } \\
\hline & & 2.375 & 0.596 & \\
\hline & & 2.469 & 0.432 & \\
\hline Clinoptilolite & \multirow{2}{*}{$\begin{array}{l}\text { Concentration range (50 to } \\
250 \mathrm{mg} \mathrm{L}^{-1} \text { ) }\end{array}$} & 11.2 & 2.71 & \multirow[b]{2}{*}{ (Wang at al. 2007) } \\
\hline and modified Zeolite & & 22.64 & 3.639 & \\
\hline \multirow[t]{3}{*}{ Natural Clinoptilolite } & Three temperatures $\left(25,40\right.$ and $\left.55^{\circ} \mathrm{C}\right)$ & 6.05 & 6.62 & \multirow{3}{*}{ (Karadag at al., 2006) } \\
\hline & \multirow{2}{*}{$\begin{array}{l}\text { Concentration range ( } 25 \text { to } \\
150 \mathrm{mg} \mathrm{L}^{-1} \text { ) }\end{array}$} & 4.75 & 5.50 & \\
\hline & & 3.76 & 4.01 & \\
\hline Clinoptilolite & Concentration range ( 0 to $200 \mathrm{mg} \mathrm{L}^{-1}$ ) & 6.54 & 10.66 & $\begin{array}{l}\text { (Weatherley and } \\
\text { Miladinovic, 2004) }\end{array}$ \\
\hline
\end{tabular}

\section{3.3. Regeneration studies}

379 The regeneration efficiency of the natural zeolites was higher than that for the

380 synthetic zeolite, MesoLite (Fig. 7). For instance, the regeneration efficiency of

381 MesoLite was $68 \%$ during the synthetic trials and $50 \%$ during the real wastewater

382 trials. In comparison, the regeneration efficiency of the natural zeolites ranged from

38390 to $100 \%$. As such, whilst MesoLite provided a higher operational capacity, the

384 ability to utilise the available capacity over prolonged periods may be a challenge. An

385 explanation for this could be the strong $\mathrm{Ca}^{2+}$ binding with MesoLite as a consequence 
386 of MesoLite's much lower Si:Al ratio. The higher proportion of Al substitution within 387 the lattice structure enables the $\mathrm{Ca}^{2+}$ ion to potentially bind with two $\mathrm{Al}$ ions and form 388 a stable inner sphere complex that is difficult to exchange (Ruiz-Salvador et al., 389 1998). Thus, regeneration for MesoLite needs to be optimised to ensure that the 390 improved capacity can be maintained over multiple cycles so that the material can be 391 usable in practice.

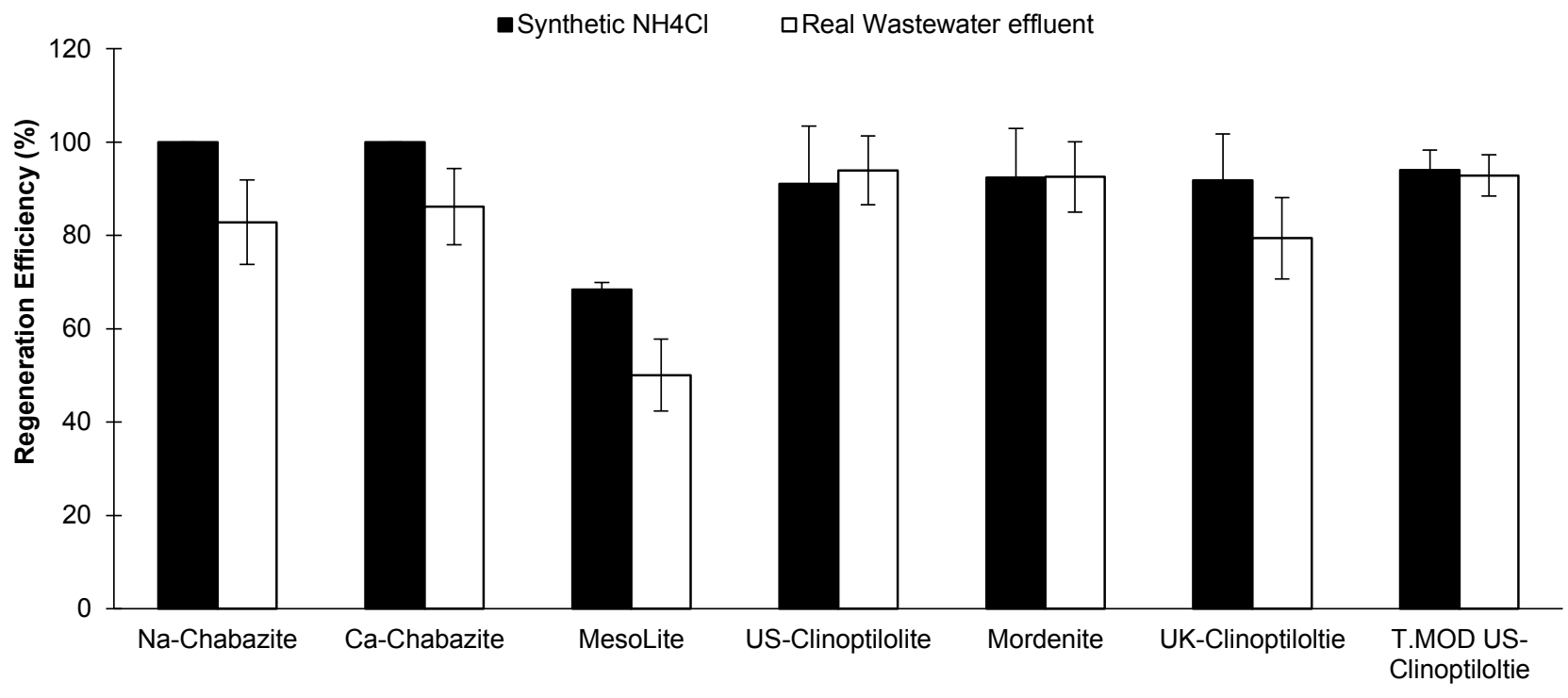

393 Fig. 7 Comparison of the average regeneration efficiency over a five cycle sequence 394 for the seven different zeolites treating synthetic and real wastewater. 


\section{Conclusion}

397 The synthetic zeolite MesoLite showed higher capacity and higher removal efficiency 398 than the natural zeolites, reaching a saturation capacity of 4.6 meq $\mathrm{NH}_{4}^{+} \mathrm{g}^{-1}$ relative 399 to an average of $1.5 \mathrm{meq} \mathrm{NH}_{4}{ }^{+} \mathrm{g}^{-1}$ for the natural zeolites. Overall, the capacity of all 400 zeolites was significantly reduced when pre-treated into the calcium form with 401 Chabazite being most heavily impacted. The natural zeolites were more effectively 402 regenerated with a $1 \mathrm{M} \mathrm{NaCl}$ solution with restricted regeneration efficiency observed 403 for MesoLite. The Freundlich model adjusted to the experimental data better than the 404 Langmuir model, with MesoLite scoring the highest coefficient $\mathrm{K}_{\mathrm{F}}$ of 7.28.

405

\section{5. Acknowledgements}

407 The authors acknowledge the financial support of the project sponsors Thames 408 Water, Severn Trent, Anglian Water, Yorkshire Water and Scottish Water, as well as 409 UK-US Fulbright and Lloyd's of London.

\section{6. References}

412 Aarts A., Berends A., Boeije G., Calcinai D., Cerbelaud E., Certa H., Egmond R., 413 Elsmore R., Fox, K., Lopez I., Masscheleyn P., Richner R., Schul W., Steber J., 414 Stevens C., Toy R., Wijk W., and Wind T. 2004. "Zeolite A." Human \& 
$416 \quad$ Cleaning Product 9(1344):p53.

417 Almutairi A., Laurence R., and Weatherley L. 2015. "Intensification of Ammonia 418 Removal from Waste Water in Biologically Active Zeolitic Ion Exchange 419 Columns." Journal of Environmental Management 160:128-38.

420 Armbruster T., and Gunter M. E. 2001. "Crystal Structures of Natural Zeolites." $421 \quad$ Reviews in Mineralogy and Geochemistry 45(1):1-67.

422 Barrer R., and Meier W. M. 1959. "Exchange Equilibria in a Synthetic Crystalline 423 Exchanger." Transactions of the Faraday Society 55:130.

424 Basaldella E. I., Sanchez R. M., and Tara J. C. 1998. "Iron Influence in the $425 \quad$ Aluminosilicate Zeolites Synthesis." Clays and Clay Minerals 46(5):481-86.

426 Canfield D., Glazer A., and Falkowski P. 2010. "REVIEW The Evolution and Future of 427 Earth 's Nitrogen Cycle." Science 330:192-96.

428 Channon Y., Catlow C., Jackson R., and Owens S. L. 1998. "A Computational 429 Investigation into the Effect of Extra Framework Cations on the Structural 430 Composition of Heulandite-Type Zeolites." Microporous and Mesoporous $431 \quad$ Materials 24(4-6):153-61.

432 Cooney D.O. 1998. Adsorption Design for Wastewater Treatment. CRC Press (1833).

433 Dyer A. 1998. An Introduction to Zeolite Molecular Sieves. USA: Wiley-Blackwell.

434 Eisenman G. 1962. "Cation Selective Glass Electrodes and Their Mode of 
436 Erdoğan B.C., and Ülkü S. 2011. "Ammonium Sorption by Gördes Clinoptilolite Rich 437 Mineral Specimen." Applied Clay Science 54(3-4):217-25.

438 Faithful N.T. 1986. The Analysis of Agricultural Meterials. Oxford, UK: Wallingford.

439 Fletcher P., and Townsend R. T. 1982. "Exchange of Ammonium and Sodium lons in $440 \quad$ Synthetic Faujasites." Journal of the Chemical Society, Faraday Transactions 1 $441 \quad 78(6): 1741$.

442 Hankins N. P., Pliankarom S., and Hilal N. 2004. "An Equilibrium Ion-Exchange Study 443 on the Removal of $\mathrm{NH} 4$ + Ion from Aqueous Effluent Using Clinoptilolite." $444 \quad$ Separation Science and Technology 39(15):3639-63.

445 Hankins N.P., Pliankarom S. and Hilal N. 2005. "Removal of $\mathrm{NH} 4+$ lon from $\mathrm{NH} 4 \mathrm{Cl}$ 446 Solution Using Clinoptilolite: A Dynamic Study Using a Continuous Packed-Bed 447 Column in Up-Flow Mode." Separation Science and Technology 39(6):1347-64.

448 Huijie L., and Chandran K. 2010. "Factors Promoting Emissions of Nitrous Oxide and $449 \quad$ Nitric Oxide from Denitrifying Sequencing Batch Reactors Operated with $450 \quad$ Methanol and Ethanol as Electron Donors." Biotechnology and Bioengineering $451 \quad$ 106(3):390-98.

452 Inglezakis, V. J. 2005. "The Concept of 'Capacity' in Zeolite Ion-Exchange Systems." 453 Journal of Colloid and Interface Science 281(1):68-79.

454 Jama M. A., and Yocel H. 1989. "Equilibrium Studies of Sodium-Ammonium, 

Potauium-Ammonium and Calcium-Ammonium Exchanges on Clinoptilolite 456 Zeolite." Separation Science and Technology 24(15):1393-1416.

457 Jorgensen S.E., Libor O., Lea G., and Barkacs K. 1976. "Ammonia Removal by Use 458 of Clinoptilolite." Water Research 10(3):213-24.

459 Kantiranis N., Sikalidis K., Godelitsas A., Squires C., Papastergios G., and Filippidis 460 A. 2011a. "Extra-Framework Cation Release from Heulandite-Type Rich Tuffs on 461 Exchange with NH4+." Journal of Environmental Management 92(6):1569-76.

462 Kantiranis N., Sikalidis K., Godelitsas A., Squires C., Papastergios G., and Filippidis 463 A. 2011b. "Extra-Framework Cation Release from Heulandite-Type Rich Tuffs on 464 Exchange with NH4+." Journal of Environmental Management 92(6):1569-76.

465 Karadag D., Koc Y., Turan M., and Armagan B. 2006. "Removal of Ammonium Ion 466 from Aqueous Solution Using Natural Turkish Clinoptilolite." Journal of $467 \quad$ Hazardous Materials 136(3):604-9.

468 Klieve J. R., and Semmens M. J. 1980. "An Evaluation of Pretreated Natural Zeolites 469 for Ammonium Removal." Water Research 14(2):161-68.

470 Lei L., Li X., and Zhang X. 2008. "Ammonium Removal from Aqueous Solutions $471 \quad$ Using Microwave-Treated Natural Chinese Zeolite." Separation and Purification $472 \quad$ Technology 58:359-66.

473 Lin L., Lei Z., Wang L., Liu X., Zhang Y., Wan C., Lee, D.J., and Tay J. H. 2012. 474 "Adsorption Mechanisms of High-Levels of Ammonium onto Natural and $\mathrm{NaCl}-$ 
476 Mackinnon I., Millar, Graeme J., and Stolz W. 2010. "Low Temperature Synthesis of 477 Zeolite N from Kaolinites and Montmorillonites." Applied Clay Science 48(4):622$478 \quad 30$.

479 Malovanyy A., Sakalova H., Yatchyshyn Y., Plaza E., and Malovanyy M. 2013. 480 "Concentration of Ammonium from Municipal Wastewater Using lon Exchange $481 \quad$ Process." Desalination 329:93-102.

482 McAdam E. J., Luffler D., Martin-Garcia N., Eusebi L., Lester J. N., Jefferson B., and 483 Cartmell E. 2011. "Integrating Anaerobic Processes into Wastewater Treatment." $484 \quad$ Water Science and Technology 63(7):1459-66.

485 Metropoulos, K., Maliou, E., Loizidou, M., and Spyrellis M. 1993. "Comparative 486 Studies between Synthetic and Natural Zeolites for Ammonium Uptake." $487 \quad$ Environmental Science 7:1507-18.

488 Miladinovic N., and Weatherley L. 2008. "Intensification of Ammonia Removal in a 489 Combined Ion-Exchange and Nitrification Column." Chemical Engineering $490 \quad$ Journal 135(1-2):15-24.

491 Milton, R., M. 1959. “'Molecular Sieve Adsorbents'." US Patent 2882243.

492 Mohan D., Singh K.P., Singh G., and Kumar K. 2002. "Removal of Dyes from 493 Wastewater Using Flyash, a Low-Cost Adsorbent†." Industrial \& Engineering $494 \quad$ Chemistry Research 41(15):3688-95. 
495 Mohan D., and Singh K. P. 2002. "Single- and Multi-Component Adsorption of 496 Cadmium and Zinc Using Activated Carbon Derived from Bagasse-an 497 Agricultural Waste." Water Research 36(9):2304-18.

498 Ouki S. K., and Kavannagh M. 1997. "Performance of Natural Zeolites for the 499 Treatment of Mixed Metal-Contaminated Effluents." Waste Management \& $500 \quad$ Research 15(4):383-94.

501 Querol X., Moreno N., Umaa J. C., Alastuey A., Hernández E., López-Soler A., and 502 Plana F. 2002. "Synthesis of Zeolites from Coal Fly Ash: An Overview." $503 \quad$ International Journal of Coal Geology 50(1-4):413-23.

504 Ruiz-Salvador A., Lewis, D., Rubayo-Soneira J., Rodriguez-Fuentes G., Sierra L., 505 and Catlow C. 1998. "Aluminum Distribution in Low Si/Al Zeolites: Dehydrated $506 \quad$ Na-Clinoptilolite." Journal of Physical Chemistry 102:8417-25.

507 Sherry H.S. 1966. "The Ion-Exchange Properties of Zeolites. I. Univalent Ion $508 \quad$ Exchange in Synthetic Faujasite." Journal of Physical Chemistry 70(4):1158-68.

509 Shoumkova A., and Stoyanova V. 2013. "Zeolites Formation by Hydrothermal Alkali 510 Activation of Coal Fly Ash from Thermal Power Station 'Maritsa 3', Bulgaria." $511 \quad$ Fuel 103:533-41.

512 Sprynskyy M., Lebedynets M., Terzyk A., Kowalczyk P., Namieśnik J., and 513 Buszewski B. 2005. "Ammonium Sorption from Aqueous Solutions by the Natural 514 Zeolite Transcarpathian Clinoptilolite Studied under Dynamic Conditions." 515 Journal of Colloid and Interface Science 284(2):408-15. 
516 Svetich R. 1993. Long-Term Use of Clinoptilolite in the Treatment of Sewage at 517 Tahoe-Truckee Sanitation Agency. Truckee, California. Califo.

518 Teichgraber B., and Stein A. 1994. "Nitrogen Elimination from Sludge Treatment 519 Reject Water - Comparison of the Steam-Stripping and Denitrification $520 \quad$ Processes." Water Science and Technology 30(6 pt 6):41-51.

521 Thornton A., Pearce P., and Parsons S. 2007. "Ammonium Removal from Solution 522 Using Ion Exchange on to MesoLite, an Equilibrium Study." Journal of $523 \quad$ Hazardous Materials 147(3):883-89.

524 Wang L., and Sun H. 2013. "Prediction of $\mathrm{Na}+/ \mathrm{NH} 4$ + Exchange in Faujasite Zeolite 525 by Molecular Dynamics Simulation and Thermodynamic Integration Method." 526 The Journal of Physical Chemistry C 117(27):14051-60.

527 Wang Y., Liu S., Xu, Z.,Han T., Chuan S., and Zhu T. 2006. "Ammonia Removal from 528 Leachate Solution Using Natural Chinese Clinoptilolite." Journal of Hazardous $529 \quad$ Materials 136(3):735-40.

530 Wang Y. F., Lin F., and Pang W. Q. 2007. "Ammonium Exchange in Aqueous 531 Solution Using Chinese Natural Clinoptilolite and Modified Zeolite." Journal of $532 \quad$ Hazardous Materials 142(1-2):160-64.

533 Watanabe Y., Yamada H., Kokusen H., Tanaka J., Moriyoshi Y., and Komatsu Y. 534 2003. "Ion Exchange Behavior of Natural Zeolites in Distilled Water, Hydrochloric 535 Acid, and Ammonium Chloride Solution." Separation Science and Technology $536 \quad 38(7): 1519-32$. 
537 Watanabe Y., Yamada H., Tanaka J., Komatsu Y., and Moriyoshi Y. 2004. 538 "Ammonium Ion Exchange of Synthetic Zeolites: The Effect of Their Open539 Window Sizes, Pore Structures, and Cation Exchange Capacities." Separation $540 \quad$ Science and Technology 39(9):2091-2104.

541 Weatherley L. R., and Miladinovic N. D. 2004. "Comparison of the Ion Exchange $542 \quad$ Uptake of Ammonium Ion onto New Zealand Clinoptilolite and Mordenite." Water $543 \quad$ Research 38(20):4305-12. 